\title{
PEDOGÊ NESE NUMA SEQÜÊNCIA LATOSSOLO-ESPODOSSOLO NA REGIÃO DO ALTO RIO NEGRO, AMAZONAS ${ }^{(1)}$
}

\author{
A. L. MAFRA (2), A. A. W. MIKLÓS(3), B. VOLKOFF(4) \& A. J . MELFI(5)
}

\begin{abstract}
RESUMO
O trabalho trata da formação de solos arenosos hidromórficos com morfologia de Espodossolo, encontrados em extensas planícies, onde ocorrem áreas i soladas de L atossolos, em terrenos ondulados e bem drenados de colinas. O objetivo do estudo é el ucidar a existência de relação pedogenética num sistema Latossolo-E spodossolo, verificando o possível desenvol vimento dos solos arenosos por transformação dos Latossolos. Para tanto, foram caracterizados a morfologia dos solos e seus atributos fisicos, químicos e mineralógicos. Os solos estudados apresentam desenvolvimento autóctone e filiação com a rocha granítica do embasamento, mostrando relação genética lateral entre si. Pode-se admitir transformação do Latossolo em areia branca, que se verifica numa escala métrica, de acordo com as condições de saturação hídrica crescente, provocando amareleci mento, seguido de gleização, na periferia da colina. Nesta zona, ocorre empobrecimento em argila em subsuperfície, que se estende lateralmente na planície, onde se encontram, de início, o material arenoso e, em seguida, os Espodossolos hidromórficos. Esta disposição evidencia o desenvolvimento dos Espodossolos posteriormente à formação das areias. 0 principal processo pedogeoquímico envolvido na perda de argila seria a acidólise, que provoca dissolução da gi bbsita e caulinita. Nesse caso, a transformação dos solos teria papel preponderante na evolução do modelado com aplai namento geral do relevo.
\end{abstract}

Termos para indexação: morfogênese; podzolização; solos hidromórficos; solos tropicais.

\footnotetext{
(1) Parte da Tese de Doutorado do primeiro autor, apresentada à Escola Superior de Agricultura "Luiz de Queiroz" - ESALQ. Recebido para publicação em março de 2000 e aprovado em outubro de 2001.

(2) Professor da Universidade do Estado de Santa Catarina - UDESC. Caixa Postal 281, CEP 88520-000 Lages (SC). Bolsista do CNPq. E-mail: a2alm@cav.udesc.br

(3) Professor da Faculdade de Filosofia, Letras e Ciências Humanas, Departamento de Geografia, Universidade de São Paulo - USP. Caixa Postal 2530. CEP 05508-900 São Paulo (SP). E-mail: awmiklos@usp.br

(4) Pesquisador aposentado do "Institut de Recherche pour le Dével oppment" - IRD. E-mail: volkoff@ns.ird.fr

(5) Professor Titular do Departamento de Solos e Nutrição de Plantas, ESALQ. E-mail: ajmelfi@usp.br
} 


\title{
SUMMARY: PEDOGENESIS IN AN OXISOL-SPODOSOL SEQUENCE AT THE UPPER RIO NEGRO REGION, AMAZONIA
}

\begin{abstract}
This paper deals with thegenesis of hydromor phic sandy soils with spodosol morphol ogy found in extensive flat surfaces, in which isolated zones with undulating relief emerge, containing well drained oxisols. The objective of this study was to explain the existence of pedogenetic relationship in an oxisol-spodosol system, and to verify the possibl edevel opment of the sandy materials as a consequence of oxisol transformation. For this purpose, we characterized the morphology of the soils and their physical, chemical and mineralogical attributes. The studied soils showed autochthonous development and filiation to granitic rock of thecrystal linebasement, displaying lateral genetic relationship between them. Thus, we can admit the occurrence of oxisol transformation, verified in a metric scale, caused by increasing waterlogging conditions. As a result, soil yellowing was found, followed by gleization near the edge of the hill. In this zone, clay depletion was evidenced in the subsuperficial soil layer, extending laterally towards theplain, with theappearanceof sandy materials (white sands) near the hill, followed by hydromorphic spodosol. This disposition suggests that evolution of the spodosol occurred after sand formation occurred later. The main pedogeochemical process involved in clay removal would beacidolysis, which causes gibbsiteand kaolinitedissolution. Thus, soil transformation would probably have played a preponderant rolein thelandscape evolution resulting in overall relief planation.
\end{abstract}

Index terms: hydromorphic soils, morphogenesis, podzolization, spodosol, tropical soil.

\section{NTRODUÇÃO}

Os trabalhos de reconhecimento pedológico da região do alto rio Negro, na Amazônia brasileira, evidenciam extensas áreas com solos arenosos hidromórficos, como Neossolos Quartzarênicos e Espodossolos, que ocupam mais de $100.000 \mathrm{~km}^{2}$, somente nos estados do Amazonas e Roraima (E MBRAPA, 1981), ocorrendo também na Colômbia eVenezuela (Gavaud et al., 1986).

Mais recentemente, estudos pedológicos em escala regional elocal identificaram várias unidades pedogeomórficas, demonstrando a diversidade de solos na região. As áreas mais altas em relação à planície geral são formadas por el evações policonvexas, com até $80 \mathrm{~m}$ de altura e predominância de Latossolos Vermelho-Amarelos. Em outra unidade, caracterizada por col inas baixas isoladas com até $15 \mathrm{~m}$ de altura, ocorrem solos amarelados. A maior parte da área é constituída por superfícies aplainadas, com presença de areias brancas não estratificadas, que podem atingir cerca de 10 m de profundidade (Dubroeucq \& Vol koff, 1998; Dubroeucq et al., 1999). Todas estas unidades apresentam-se ordenadamente distribuídas numa escala regional, revelando a existência de relação pedogenética entreelas (Grzebyk \& Dubroeucq, 1994).

A formação desses solos arenosos pode ser atribuída a duas causas principais: das quais uma seria relacionada com a deposição de sedi mentos nas bordas dos vales (Klinge, 1965; Sombroek, 1984), e outra com a gênese das areias a processos pedogenéticos, que levariam à transformação de solos mais argilosos, como Latossolos, com progressiva perda de argila, ligada à condição de saturação hídrica (Lucas et al., 1984; Dubroeucq et al., 1991). Em apoio a esta hipótese, verifica-se que este sistema Latossolo-E spodossolo ocorre em diversas situações nas zonas tropicais úmidas, com relatos na América do Sul (Klinge, 1965; Volkoff, 1985), na África (Brammer, 1973; Schwartz, 1987) e na Indonésia (Thomas et al., 1999).

No caso da bacia do alto rio Negro, pouco se conhece sobre a formação desses solos arenosos, o que se deve à dificuldade de acesso e à impossibilidade da abertura de trincheiras num ambiente pantanoso, com uma camada arenosa e, algumas vezes, presença de horizonte $B h$ endurecido (Dubroeucq \& Blancaneaux, 1987).

O presente artigo trata do estudo detalhado de uma paisagem na região do al to rio Negro, dominantemente plana, com solos arenosos hidromórficos como Neossol os Quartzarênicos e Espodossolos e col inas isoladas com L atossol os argi losos, e tem por objetivo caracterizar seus constituintes bi ofísicoquímicos e mineralógicos, com vistas em elucidar a existência de uma relação genética LatossoloEspodossolo. 


\section{MATERIAL E MÉTODOS}

A área de estudo localiza-seno noroeste do estado doAmazonas (01007'48'N e6648'29'W), nokm 199,8 da rodovia BR307, nas proximidades de Cucuí (Figura 1). Os terrenos situam-se sobre o embasamento cristalino, com litol ogia representada por granitos do Complexo Guianense, formados no pré cambriano. O dima é do tipotropical constantemente úmido (Afi), segundo a classificação de Köppen. A precipitação pluviométrica é próxima de $3.000 \mathrm{~mm}$ por ano, sem ocorrência de estação seca. A vegetação é do tipo floresta tropical densa nos terrenos elevados, passando para campinarana nas áreas aplainadas (Brasil, 1976).

A altimetria do terreno foi efetuada a partir de dois transectos perpendiculares entresi, abrangendo uma col ina baixa ea planíciecircundante, numa área central de $120 \times 120 \mathrm{~m}$. A macromorfologia dos sol os foi descrita quanto à cor, textura, estrutura, porosidade e consistência do solo (Lemos \& Santos, 1996), em seis trincheiras. Na colina, a variabilidade dos atributos morfológi cos do solo foi avaliada com auxílio de trado comum. J á na planíciehidromórfica, para a realização das sondagens, foi necessária a utilização de um amostrador metálico com quatro centímetros de diâmetro e dois metros de comprimentoe sistema de vedação na partesuperior, desenvolvido pelo autor. A distância máxima entre os pontos de amostragem foi de $25 \mathrm{~m}$. A micromorfologia dos materiais de alteração em meia-encosta e na borda da colina foi descrita em lâminas del gadas, obtidas a partir deamostras indeformadas (Castro, 1985), seguindo-se a terminologia apresentada por Bullock et al. (1985).

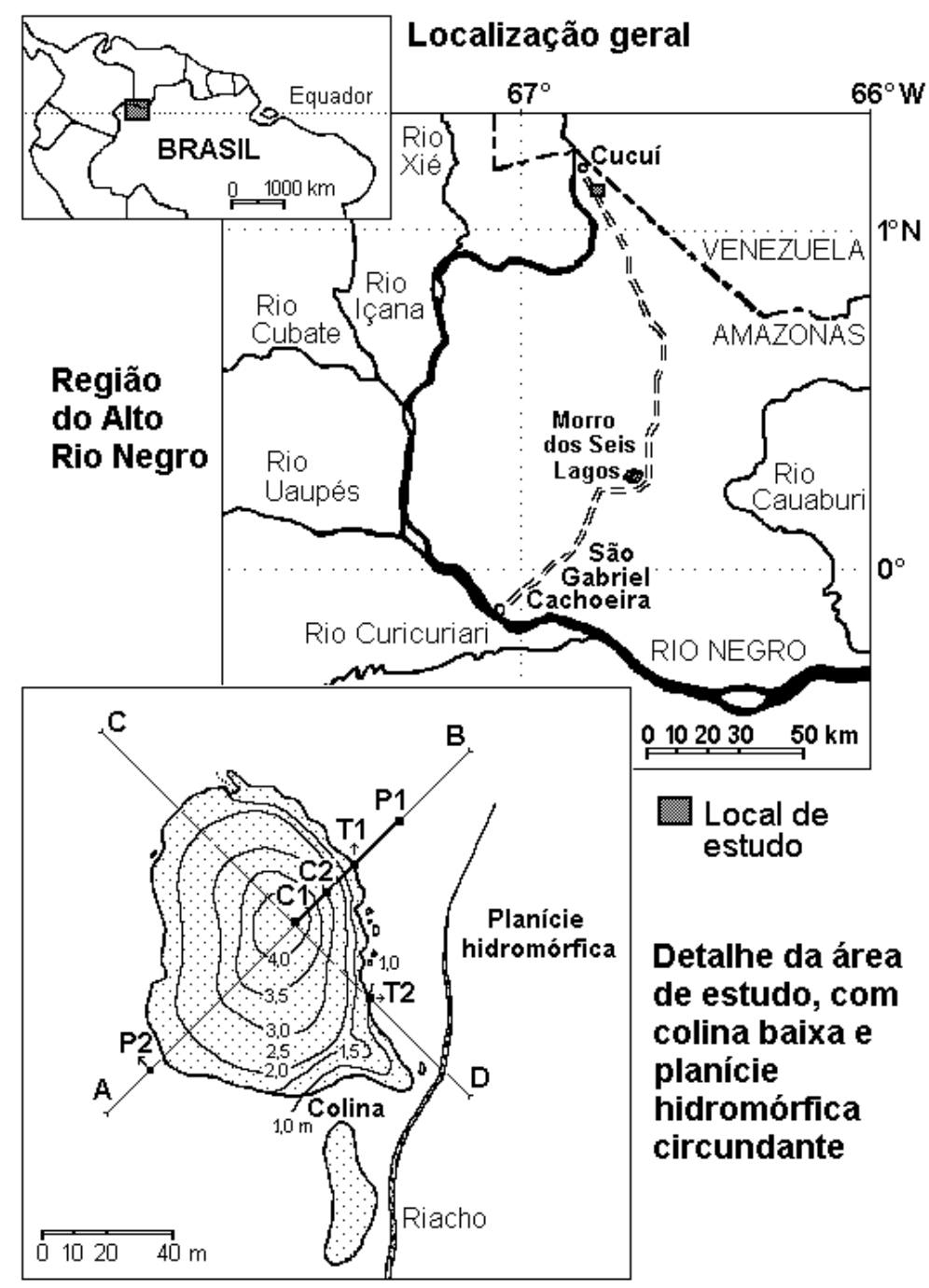

Figura 1. Localização da área de estudo na região do alto rio Negro, nas proximidades de Cucuí, AM, às margens da rodovia BR 307, com detal he da colina estudada, mostrando os alinhamentos AB e CD e as curvas de nível eqüidistantes em 0,5 m. 
A uniformidade dos materiais do solo e a filiação ao granito foram avaliadas pel o exame morfoscópico dos grãos de areia grossa $(2-0,25 \mathrm{~mm})$ e fina $(0,25-$ $0,05 \mathrm{~mm}$ ) ao microscópio ótico, estimando-se arredondamento e esfericidade por comparação (Krumbein \& Sloss, 1963). As classes de arredondamento consideradas foram: angular $(<0,20)$; subangular $(0,21-0,40)$; subarredondada $(0,41-0,60)$; arredondada $(0,61-0,80)$ e bem arredondada $(>0,80)$. Para esfericidade foram consideradas quatro classes: bastonada $(<0,40)$; tabular $(0,41-0,60)$; ovalada $(0,61-0,80)$ e eqüidimensional $(>0,81)$. A partir do produto das freqüências de 100 grãos e dos valores médios de intervalo de classe, foram obtidas as médias ponderadas de arredondamento e esfericidade (Suguio, 1973).

Os atributos físicos do solo analisados foram densidade e granulometria. A densidade foi estimada em amostras coletadas em anéis volumétricos de $100 \mathrm{~cm}^{3}$, com três repetições. A granulometria foi analisada pelo método do densímetro, em amostras dispersas com hexametafosfato de sódio e hidróxido de sódio (Camargo et al., 1986). As areias foram separadas em cinco frações: (a) muito grossa, de 2,0 a 1,0 mm; (b) grossa, de 1,0 a 0,5 mm; (c) média, de 0,5 a $0,25 \mathrm{~mm}$; (d) fina, de 0,25 a 0,1 mm e (e) muito fina, de 0,1 a $0,05 \mathrm{~mm}$, a partir das quais foi calculado o diâmetro médio (Folk \& Ward, 1957), empregandose o programa "Phi"(Van Lier \& Vidal-Torrado, 1992).

As determinações químicas foram $\mathrm{pH}$ em água e $\mathrm{KCl} \mathrm{M}$, carbono orgânico, bases trocáveis $\left(\mathrm{Ca}^{2+}, \mathrm{Mg}^{2+}\right.$, $\left.\mathrm{K}^{+}\right), \mathrm{Al}^{3+}, \mathrm{H}+\mathrm{Al}$ e CTC. Os teores de $\mathrm{Si}, \mathrm{Al}$ e Fe foram determinados em extrato de solo submetido ao ataque sulfúrico, a partir dos quais foi calculado o índice Ki (Camargo et al., 1986).

Os perfis de sol o for am classificados com base nos atributos morfológicos e analíticos de acordo com o Sistema Brasileiro de Classificação de Solos (EMBRAPA, 1999).

A mineralogia das frações silte e argila foi caracterizada por difração de raios- $\mathrm{X}$, em equipamento Philips PW 1830, com tubo decobre, operado a $30 \mathrm{~mA}$ e $40 \mathrm{kV}$, com velocidade de $2{ }^{\circ} 2 \theta$ por minuto. As amostras foram previamente submetidas à eliminação de matéria orgânica e óxidos de ferro. O silte foi separado por centrifugação, em amostras dispersas com $\mathrm{NaOH}$ 0,1 M, montadas na forma de pó e irradiadas de 5 a $60^{\circ} 2 \theta$. As argilas foram saturadas com $\mathrm{K}$ e $\mathrm{Mg}$, analisadas na forma orientada de 5 a $30^{\circ} 2 \theta$, sendo tratadas com etilenogl icol e aquecidas a 350 e $550^{\circ} \mathrm{C}$, quando necessário (J ackson, 1969; Camargo et al., 1986). A identificação dos minerais foi feita de acordo com as distâncias interplanares (Brindley \& Brown, 1984; Moore \& Reynolds, 1989).

A estimativa da concentração de gibbsita e caulinita na fração argila foi feita por anál isetérmica diferencial em amostras livres de matéria orgânica eóxidos deferro, esaturadas com Mg. A quantificação baseou-se nas áreas dos picos endotérmicos, a $320^{\circ} \mathrm{C}$, para gibbsita, e a $550^{\circ} \mathrm{C}$, para caulinita, calculados em relação a uma curva-padrão com concentrações crescentes para cada um desses minerais (Camargo et al., 1986).

\section{RESULTADOS E DISCUSSÃO}

\section{Aspecto superficial do terreno}

A área de estudo situa-se numa planície, onde emergem terrenos pouco el evados com até $3 \mathrm{~m}$ de altura e superfície convexa. A colina estudada tem uma área de aproximadamente 0,6 ha, limites recortados e arredondados, com aspecto amebói de e digitado em algumas porções. A zona de contato entre col ina e planície apresenta variações quantoà forma e desnível do terreno, profundidade da rocha equantidade de matacões. Na porção oeste da colina, em vertentes mais longas, os contornos da zona de contato são pouco recortados, e a rocha, menos fraturada, aflora, estando disposta acima do nível do lençol freático da planície. Nas demais porções, onde as vertentes sãomais curtas, surgem barrancos inclinados na borda da colina. A rocha encontra-se em subsuperfície, bastante fraturada. É comum a presença de matacões isolados na superfície da planície hidromórfica perto da colina. No sopé da colina, podem ocorrer rebaixamentos do terreno, formando depressões fechadas, que adquirem dimensões métricas, com forma amebóide e contornos arredondados. O sol o nas paredes detais depressões é bruno-amarelado, relativamente argil losoe, na sua base, éarenoso com muito cascalho granítico.

Na planície hidromórfica, a superfície do solo apresenta montícul os cônico-arredondados, com até $30 \mathrm{~cm}$ de altura e densidade de um a cinco por $\mathrm{m}^{-2}$. Estas estruturas são formadas por dejeções de minhocas, constituídas por material organomineral. O lençol freático situa-se entre 10 e $20 \mathrm{~cm}$ de profundidade, aflorando nas proximidades do eixo de drenagem, onde ocorrem inúmeras depressões centimétricas isoladas. À medida que seaproximam do eixo de drenagem, essas depressões tornam-se mais abundantes e interligadas.

\section{Macromorfologia do solo}

Os solos da colina são bem drenados, argiloarenosos a argilosos, com seqüência de horizontes A, BA, Bw, BC, C eC/R, classificados como L atossol os Amarelos. O horizonte Bw é pouco espesso, com menos de 1,5 m de espessura, tem estrutura composta, maciça e granular muito pequena forte; no topo da colina, é amarelado e em meia-encosta, bruno-forte. Em direção à base, a estrutura torna-se 
progressivamente maciça. O saprolito que compõe os horizontes $\mathrm{C}$ e C/R é espesso e avermel hado na porção superior da colina (Figura 2), passando a amarelado e menos espesso em direção à parte inferior das vertentes. Nas bordas da colina, o horizonte Bw, com espessura reduzida, sobrepõe-se a um material maciço e mosqueado. Mais abaixo, em profundidade, sob condições de hidromorfismo permanente, encontra-se um saprolito composto por porções acinzentadas isoladas, que coalescem em direção à base do perfil. À medida que o material vai-se tornando progressivamente acinzentado, a textura também muda, tornando-se gradualmente arenosa. Essa diferenciação concomitante em cor e textura ocorre de forma semel hante lateralmente, com passagem progressiva do saprolito acinzentado para as areias brancas na planície hidromórfica adjacente, numa distância de um a cinco metros.
Na planície, os sol os são arenosos, com horizonte A bruno-escuro, organomineral, recobrindo uma camada de areia branca com até $80 \mathrm{~cm}$ de espessura, que constitui o horizonte $\mathrm{E}$, disposto diretamente sobre a rocha, numa faixa de 10-20 m de largura em volta da colina. À medida que se distancia da col ina, a rocha se aprofunda e a camada de areia branca fica mais espessa, recobrindo o horizonte espódico (Bh) enriquecido em matéria orgânica, localizado sobrejacente ao saprolito (Perfil P1).

O horizonte $\mathrm{Bh}$, na maior parte da área, tem consistência solta. A distribuição da matéria orgânica é heterogênea e aparece em porções milimétricas arredondadas no contato com o horizonte E. Estas porções isoladas coalescem em profundidade, formando uma camada escura, onde surgem pontuações milimétricas de areia branca. Este horizonte Bh ocorre sobre um material de
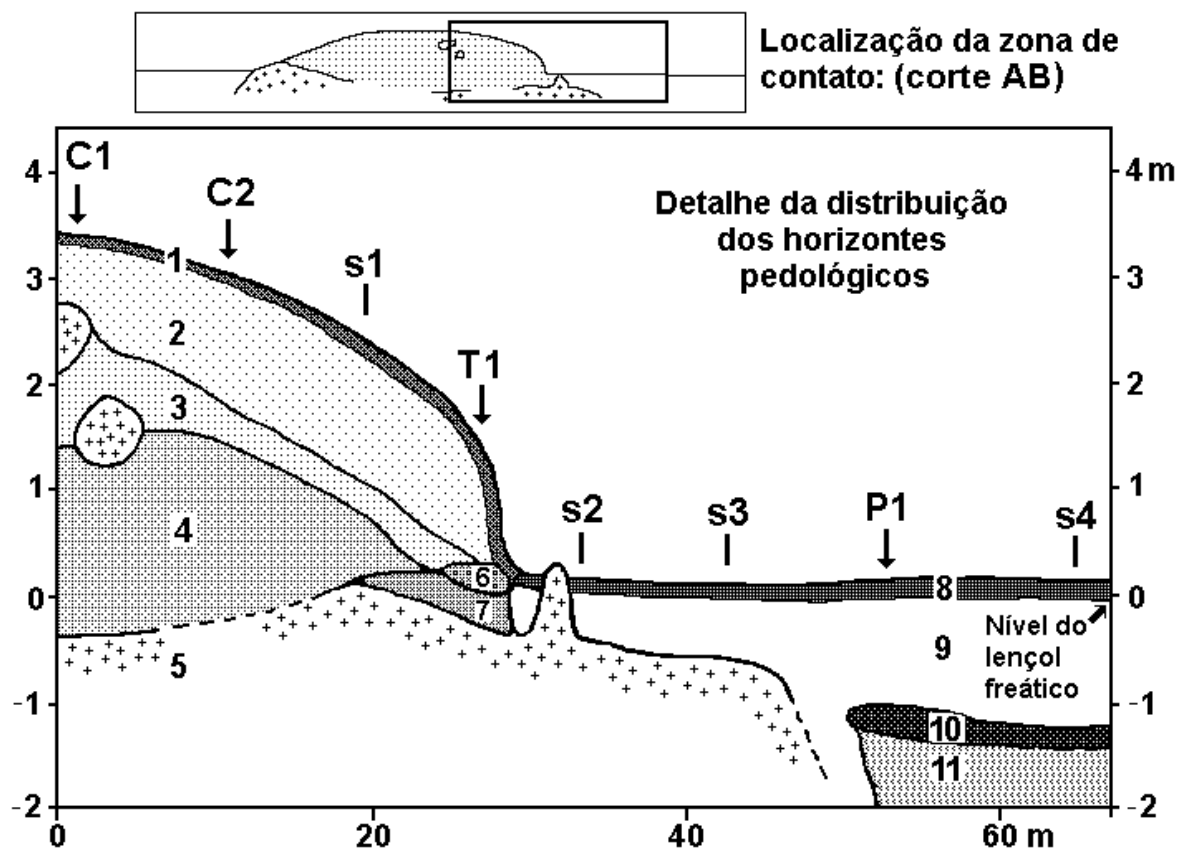

Legenda: horizontes e constituintes do solo

a) Colina:

1. Bruno-escuro (10YR 4/3); franco-arenosa; granular (Hor. A) e amarelo-brunado (10YR 6/8); franco-argilo-arenosa; granular (Hor. BA);

2. Amarelo-brunado (10YR 6/8); argilo-arenosa; maciça a granular muito pequena forte (Hor. Bw)

3. Amarelo-brunado (10YR 6/8) a bruno-forte (7.5YR 5/8); argilo-arenosa; maciça a granular muito pequena forte (Hor. BC)

4. Vermelho (2.5YR 5/8) a amarelo-brunado (10YR 6/8); franco-argilo-arenosa com cascalho e fragmentos de rocha (Hor. C)

5. Rocha (granito)

6. Oliva-claro-acinzentado (5Y 6/4) com mosqueados amarelo-avermelhados (5YR 6/6); franco-arenosa a argilo-arenosa; maciça (Hor. $\mathrm{BCg}$ ou $\mathrm{CBg}$ )

7. Bruno-oliváceo (2.5Y 4/4) a cinzento-brunado-claro (2.5Y6/2); franco-arenosa a arenosa (Hor. Cg)

b) Planície hidromórfica:

1. Bruno-escuro (10YR 4/3); arenosa; granular (Hor. A)

2. Cinzento-brunado-claro (10YR 6/2); arenosa; grãos simples (Hor. E)

3. Bruno-acinzentado-muito-escuro (10YR 3/2) a bruno-acinzentado-escuro (10YR 4/2); arenosa; grãos simples (Hor. E/Bh)

4. Cinzento-claro (2.5Y 7/2); areia-franca a franco-arenosa; maciça (Hor. Cg)

Figura 2. Localização e distribuição dos horizontes pedológicos em corte bidimensional de parte do alinhamento $A B$ ( $s=$ tradagens ou sondagens). 
alteração cinzento-claro, argilo-arenoso a argiloso que compõe o horizonte Cg. Em uma parte da planície, na porção a oeste da col ina, o horizonte Bh tem consistência dura e é mais rico em matéria orgânica. N Neste caso, a rocha sã e o saprolito estão mais próximos da superfície, a cerca de $1,4 \mathrm{~m}$ de profundidade no perfil P2. A presença de micas e feldspatos alterados é abundante e a presença de litorrelíquias centimétricas no topo do horizonte $\mathrm{Bh}$ é comum neste caso. Os solos da planície hidromórfica com presença do horizonte Bh foram classificados como Espodossol os Cárbicos.

\section{Micromorfologia do solo e morfoscopia dos grãos}

O exame micromorfológico do material de alteração evidencia a passagem do saprolito avermelhado na porção superior das vertentes, chegando ao saprolitoacinzentado na borda da colina (Quadro 1). Confirmam-se as variações na cor e textura, observadas na descrição macromorfológica.

$\mathrm{Na}$ porção intermediária da colina, perfil C2, o saprolito composto pelo horizonte $C$ mostra-se apedal, com microestrutura maciça, sem del imitação de agregados. O material é poroso com vazios irregulares interconectados, normal menteinferiores a $50 \mu \mathrm{m}$ de diâmetro. Os constituintes relacionamse com os minerais do granito, com predomínio de grãos de quartzo e presença freqüente de micas e feldspatos alterados. O material argiloso é predominantemente avermel hado com zonas amareladas, comuns, isoladas a parcialmente interconectadas (Figura 3a). A trama é porfírica a enáulica e como feições pedológicas ocorrem nódul os ferruginosos típicos, moderadamente impregnados e pseudomorfos de micas e feldspatos.

\section{Quadro 1. Atributos micromorfológicos dos materiais de alteração em meia-encosta (C2) e na borda da colina (T1)}

\begin{tabular}{|c|c|c|c|}
\hline Atributo & C 2 Hor.C $170-180 \mathrm{~cm}$ & T1 Hor. BCg 110-120 cm & T 1 Hor. CBg/Cg 130-140 cm \\
\hline $\begin{array}{l}\text { Microestrutura } \\
\text { e porosidade }\end{array}$ & $\begin{array}{l}\text { Apedal, predomínio de } \\
\text { microestrutura maciça com } \\
\text { numerosos vazios irregulares } \\
\text { interconectados, sem } \\
\text { delimitação de agregados. } \\
\text { Poros inferiores a } 50 \mu \mathrm{m}, \\
\text { freqüentes a comuns, } \\
\text { distribuição aleatória. } \\
\text { Algumas porções pouco } \\
\text { freqüentes um pouco mais } \\
\text { adensadas }\end{array}$ & $\begin{array}{l}\text { Apedal, mi croestrutura } \\
\text { maciça com transição nítida } \\
\text { para porções isoladas com } \\
\text { empilhamento de grãos } \\
\text { simples, arranjo solto, } \\
\text { formato irregular e } \\
\text { distribuição aleatória. } \\
\text { Algumas porções pouco } \\
\text { freqüentes com estrutura } \\
\text { granular moderadamente } \\
\text { desenvolvida }\end{array}$ & $\begin{array}{l}\text { Apedal, microestrutura } \\
\text { maciça muito porosa } \\
\text { passando gradualmente para } \\
\text { grãos parcialmente ligados } \\
\text { por material fino. Transição } \\
\text { nítida para porções com } \\
\text { empilhamento de grãos } \\
\text { simples, comuns, arranjo } \\
\text { solto, formato irregular e } \\
\text { interconectadas }\end{array}$ \\
\hline E squeleto & $\begin{array}{l}\text { Predomínio de quartzo, } \\
\text { granulometria heterogênea, } \\
\text { formato ovalado e contornos } \\
\text { subangulares. Micas e } \\
\text { feldspatos freqüentes, } \\
\text { parcialmente intemperizados. } \\
\text { Alguns fragmentos } \\
\text { milimétricos de granito }\end{array}$ & $\begin{array}{l}\text { Predomínio de quartzo, } \\
\text { granulometria mais grossa } \\
\text { nas porções com areia branca } \\
\text { e predomínio de areia fina } \\
\text { nos agregados granulares. } \\
\text { Formato ovalado e contornos } \\
\text { subangulares. Micas e } \\
\text { feldspatos raros }\end{array}$ & $\begin{array}{l}\text { Predomínio de quartzo, com } \\
\text { maior quantidade de cascalho } \\
\text { em relação ao horizonte BCg. } \\
\text { Formato ovalado e contornos } \\
\text { subangulares. Micas pouco } \\
\text { freqüentes e feldspatos } \\
\text { comuns }\end{array}$ \\
\hline Plasma & $\begin{array}{l}\text { Argiloso avermelhado com } \\
\text { porções irregulares } \\
\text { amareladas comuns, isoladas } \\
\text { a parcialmente } \\
\text { interconectadas, transição } \\
\text { nítida. Birrefringência } \\
\text { granoestriada e } \\
\text { indiferenciada em pontos } \\
\text { isolados }\end{array}$ & $\begin{array}{l}\text { Argiloso amarelo-oliváceo, } \\
\text { com porções isoladas } \\
\text { amarelo-avermelhadas. } \\
\text { Birrefringência } \\
\text { indiferenciada juntamente } \\
\text { com pontos isolados e } \\
\text { ocasionais com } \\
\text { birrefringência granoestriada }\end{array}$ & $\begin{array}{l}\text { Argiloso bruno-acinzentado, } \\
\text { com pontos raros e isolados } \\
\text { amarelo-avermelhados. } \\
\text { Birrefringência } \\
\text { indiferenciada e pontos } \\
\text { isolados pouco comuns com } \\
\text { birrefringência granoestriada }\end{array}$ \\
\hline Trama & $\begin{array}{l}\text { Porfírica associada a } \\
\text { inúmeras porções com trama } \\
\text { enáulica, coincidindo com as } \\
\text { zonas mais porosas do } \\
\text { material }\end{array}$ & $\begin{array}{l}\text { Enáulica nas zonas porosas e } \\
\text { mônica nas porções com areia } \\
\text { branca. Trama porfírica nos } \\
\text { agregados granulares }\end{array}$ & $\begin{array}{l}\text { Enáulica a gefúrica nas zonas } \\
\text { com microestrutura maciça e } \\
\text { mônica nas porções com grãos } \\
\text { simples }\end{array}$ \\
\hline F eições & $\begin{array}{l}\text { a) Nódulos ferruginosos } \\
\text { típicos, raros, arredondados, } \\
\text { moderadamente } \\
\text { impregnados; b) } \\
\text { Pseudomorfos de mica } \\
\text { freqüentes, pouco } \\
\text { impregnados com óxidos de } \\
\text { ferro; c) Pseudomorfos de } \\
\text { feldspatos ocasionais, parcial } \\
\text { a completamente preenchidos } \\
\text { por gibbsita microcristalina }\end{array}$ & $\begin{array}{l}\text { a) Mosqueados amarelo- } \\
\text { avermelhados em torno dos } \\
\text { canais de raízes, } \\
\text { moderadamente impregnados } \\
\text { por óxidos de ferro; b) } \\
\text { Pseudomorfos de feldspatos } \\
\text { raros; c) Pedotúbulos com 1,5 } \\
\text { mm de diâmetro, } \\
\text { preenchimento parcial e } \\
\text { descontínuo com agregados } \\
\text { granulares }\end{array}$ & $\begin{array}{l}\text { a) Mosqueados amarelo- } \\
\text { avermelhados, fraca a } \\
\text { moderadamente impregnados } \\
\text { por óxidos de ferro; b) } \\
\text { Pseudomorfos de feldspatos } \\
\text { ocasionais; c) Nódulos } \\
\text { ferruginosos típicos e } \\
\text { concêntricos, raros a } \\
\text { ocasionais, arredondados, } \\
\text { fraca a moderadamente } \\
\text { impregnados }\end{array}$ \\
\hline
\end{tabular}




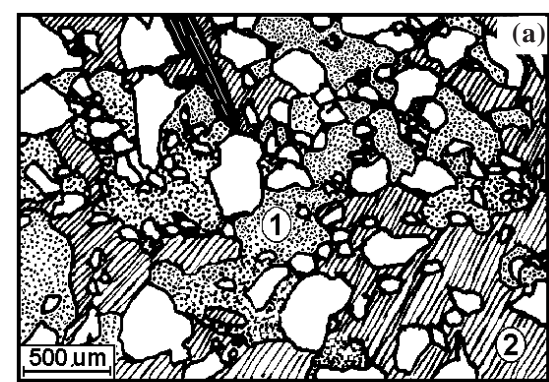

HorizonteC em meiaencosta (C2), sendo: (1) porções irregulares einterconectadas amareladas associadas ao material avermelhado. Nota-se a trama porfírica a enáulica relacionada com textura francoargilo-arenosa

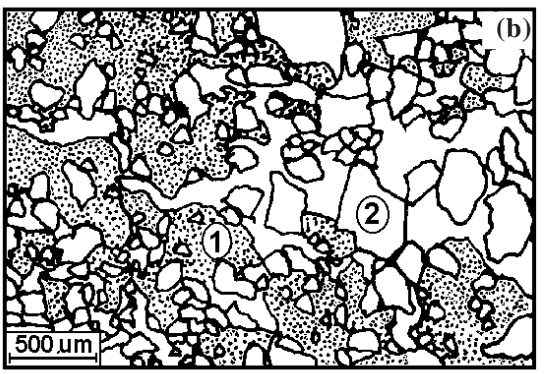

Horizonte $\mathrm{BCg}$ na borda da colina (T1), sendo: (1) zonas amarelo-oliváceas mais argilosas, com trama enáulica e (2) porções isoladas com areia branca etrama mônica.

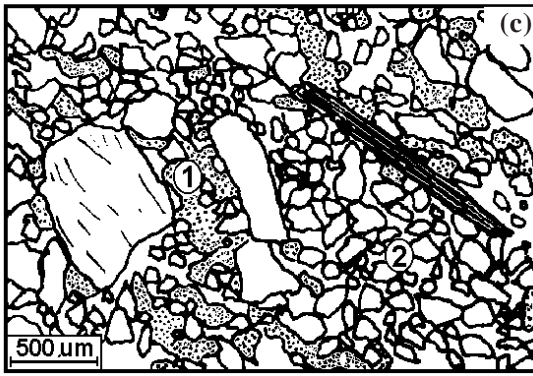

Horizonte $\mathrm{CBg} / \mathrm{Cgna}$ borda da colina (T1) sendo (1) zonas bruno-acinzentado com trama enáulica a ge fúrica e (2) porções interconectadas com areia branca. A perda de argila é ainda mais evidente em re lação à amostra anterior

Figura 3. Representação esquemática da microestrutura dos materiais de alteração na porção superior (a) e na borda da colina (b, c).

$\mathrm{Na}$ borda da colina, perfil T1, o material de alteração presente em subsuperfície pouco abaixo donível do lençol freático, compondo o horizonteBCg, étambém apedal, com microestrutura maciça. Neste caso, ocorrem porções isoladas com empilhamento degrãos simples, com arranjosolto, formatoirregular egranul ometria ligeiramentemais grossa em relação ao fundo matricial adjacente. O plasma é argiloso amarelo-oliváceo. A trama é predominantemente enáulica, passando a mônica nas porções com areia branca (Figura 3b). A mudança de coloração dos materiais deavermel hado com manchas amareladas no saprolito, em meia-encosta, para amarelooliváceo, na borda da colina, mostra relação com as condicões crescentes de hidromorfismo. Nota-se também perda de argila no mesmo sentido.

$\mathrm{Na}$ base do perfil T1, na borda da colina, o saprolito em condições de hidromorfismo permanente apresenta-se acinzentado, com aumento em quantidade e tamanho das porções arenosas com estrutura em grãos simples. A quantidade de plasma argiloso também diminui em relação à porção superior anteriormente descrita (H orizonte BCg), o que se manifesta pela trama enáulica e gefúrica nas zonas maciças, passando a mônica nas porções com areia branca (Figura 3c).
A caracterização morfoscópica envolvendo o arredondamento e esferici dade dos grãos de quartzo não permite distingui-los, se provenientes dos solos da col ina ou da planície hidromórfica, revelando uma relação genética entre eles, bem como sua filiação em relação ao granito subjacente. Os materiais apresentam arredondamento entre 0,2 e 0,4; correspondendo ao formato subangular. Os valores deesfericidadesituam-seentre 0,6 e0,8; caracterizando grãos ovalados (Figura 4). As partículas mais finas têm formato mais arredondado e eqüidimensional em relação aos grãos maiores, o que pode ser consi derado como uma evidência do intemperismo químico, que age mais intensamente sobre os grãos de menor tamanho e maior superfície específica.

\section{Densidade e granulometria do solo}

Os materiais presentes na porção superior da colina apresentam densidade do solo entre 1,17 e $1,34 \mathrm{~g} \mathrm{~cm}^{-3}$, no horizonte Bw, e valores próximos de $1,30 \mathrm{~g} \mathrm{~cm}^{-3}$, no horizonte C (Quadro 2). Na borda da col ina, o saprol ito acinzentado é mais adensado, com densidade de 1,41 $\mathrm{g} \mathrm{cm}^{-3}$, chegando a $1,59 \mathrm{~g} \mathrm{~cm}^{-3}$ no material mosqueado.

Quanto à granulometria, os solos na porção superior da colina apresentam teores de argila de 300 a $360 \mathrm{~g} \mathrm{~kg}^{-1}$ no horizonte Bw (Quadro 2). Na borda da colina, o teor de argila do horizonte amarelado superior permanece constante no perfil T2 e diminui no perfil T1. As maiores

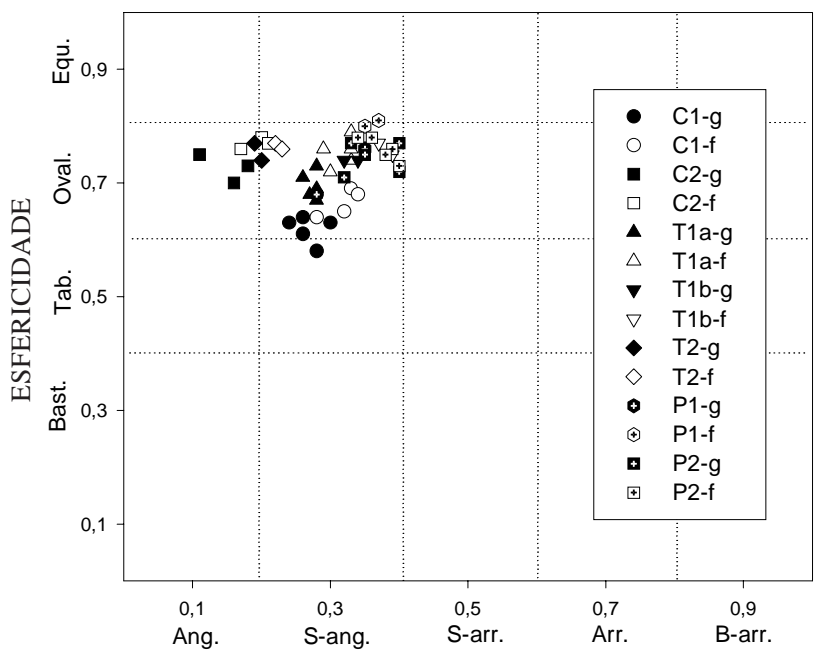

ARREDONDAMENTO

Figura 4. Valores de arredondamento eesfericidade dos grãos grandes (g) e pequenos (f) nos materiais analisados na seqüência LatossoloEspodossolo, sendo: Equ=eqüidimensional; Oval $=$ ovalado; $\mathrm{Tab}=$ tabular; Bast $=$ bastonado e Ang = angular; S-ang = subangular; S-arr = subarredondado; Arr = arredondado; B-arr = bem arredondado. 
diferenças na composição granulométrica ocorrem no sentido vertical, entre o conjunto latossólico e o saprolito acinzentado hidromórfico, cujo teor varia de 80 a $140 \mathrm{~g} \mathrm{~kg}^{-1}$ de argila. A perda de argila acentua-se em direção à planícieadjacenteà col ina, onde a areia branca se sobrepõe diretamente sobre a rocha.
Os solos da colina e da planície mostram predomínio deareia fina na camada superficial, com aumento do diâmetro médio das areias em profundidade, o que evidencia partici pação do intemperismo químico na fragmentação progressiva do quartzo em direção ao topo dos perfis. A variação mais acentuada na relação AF/AT observada em

Quadro 2. Densidade e granulometria do solo na seqüência Latossolo-Espodossolo

\begin{tabular}{|c|c|c|c|c|c|c|c|c|c|}
\hline \multirow{2}{*}{$\begin{array}{c}\text { Amostra } \\
\text { analisada }\end{array}$} & \multirow{2}{*}{ Profundidade } & \multirow{2}{*}{$\begin{array}{l}\text { Densidade } \\
\text { do solo }\end{array}$} & \multicolumn{4}{|c|}{ Fração granulométrica } & \multicolumn{2}{|c|}{ Relação } & \multirow{2}{*}{$\begin{array}{l}\text { Diâmetro } \\
\text { médio }\end{array}$} \\
\hline & & & Cascalho & Areia & Silte & Argila & Silte/argila & $\mathbf{A F} / \mathbf{A} \mathbf{T}^{(\mathbf{1})}$ & \\
\hline & $\mathrm{cm}$ & $\mathrm{g} \mathrm{cm}^{-3}$ & 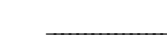 & g & 1 & {[} & & & $\mathrm{mm}$ \\
\hline \multicolumn{10}{|c|}{ C1: topo, Latossolo Amarelo distrófico argilossólico } \\
\hline BA & $10-20$ & 1,19 & 16 & 540 & 190 & 270 & 0,70 & 0,33 & 0,27 \\
\hline Bw & $50-70$ & 1,17 & 16 & 480 & 170 & 350 & 0,49 & 0,35 & 0,30 \\
\hline $\mathrm{BC}$ & $140-160$ & 1,24 & 95 & 500 & 140 & 360 & 0,39 & 0,28 & 0,36 \\
\hline $\mathrm{C}$ & $200-220$ & 1,27 & 64 & 530 & 220 & 250 & 0,88 & 0,26 & 0,41 \\
\hline \multicolumn{10}{|c|}{ C2: meia encosta, Latossolo Amarelo distrófico típico } \\
\hline BA & $10-20$ & 1,21 & 9 & 650 & 150 & 200 & 0,75 & 0,22 & 0,40 \\
\hline $\mathrm{Bw}$ & $50-60$ & 1,34 & 40 & 530 & 160 & 310 & 0,52 & 0,30 & 0,29 \\
\hline BC & $140-160$ & 1,33 & 142 & 590 & 140 & 270 & 0,52 & 0,25 & 0,40 \\
\hline $\mathrm{C}$ & $180-200$ & $--(2)$ & 69 & 570 & 210 & 220 & 0,95 & 0,25 & 0,43 \\
\hline \multicolumn{10}{|c|}{ Tla: borda da colina, Latossolo Amarelo distrófico câmbico } \\
\hline BA & $10-20$ & 1,12 & 6 & 700 & 160 & 140 & -- & 0,34 & 0,29 \\
\hline Bw1 & $50-60$ & 1,34 & 9 & 620 & 190 & 190 & 1,00 & 0,37 & 0,30 \\
\hline Bw2 & 85-95 & 1,33 & 14 & 560 & 220 & 220 & 1,00 & 0,32 & 0,28 \\
\hline $\mathrm{BCg}$ & $110-120$ & 1,50 & 10 & 650 & 190 & 160 & 1,18 & 0,34 & 0,35 \\
\hline $\mathrm{CBg}$ & $125-135$ & 1,59 & 16 & 640 & 200 & 160 & 1,25 & 0,41 & 0,26 \\
\hline $\mathrm{C}$ & $140-150$ & 1,41 & 178 & 720 & 140 & 140 & -- & 0,26 & 0,37 \\
\hline \multicolumn{10}{|c|}{ Tlb: planície hidromórfica, a 5 metros de Tla, Neossolo Quartzarênico Psamítico típico } \\
\hline A & $0-20$ & -- & 16 & 730 & 190 & 80 & -- & 0,41 & 0,24 \\
\hline C & $50-60$ & -- & 54 & 940 & 20 & 40 & -- & 0,34 & 0,33 \\
\hline \multicolumn{10}{|c|}{ T2: borda da colina, Gleissolo Háplico Tb distrófico incéptico } \\
\hline BA & $10-20$ & 1,33 & 31 & 480 & 230 & 290 & 0,79 & 0,31 & 0,27 \\
\hline $\mathrm{Bi}$ & $40-60$ & 1,45 & 45 & 490 & 190 & 320 & 0,59 & 0,31 & 0,31 \\
\hline $\mathrm{BCg}$ & $60-80$ & -- & 387 & 530 & 180 & 290 & 0,62 & 0,26 & 0,39 \\
\hline $\mathrm{CBg}$ & $80-100$ & 1,49 & 370 & 670 & 130 & 200 & 0,65 & 0,15 & 0,56 \\
\hline $\mathrm{C}$ & $120-140$ & -- & 235 & 740 & 140 & 120 & -- & 0,15 & 0,59 \\
\hline & $140-160$ & -- & 190 & 800 & 120 & 80 & -- & 0,13 & 0,62 \\
\hline \multicolumn{10}{|c|}{ P1: planície hidromórfica, Espodossolo Cárbico hidromórfico típico } \\
\hline Exc.(3) & $10-0$ & -- & 0 & 710 & 230 & 60 & -- & 0,54 & 0,17 \\
\hline A & $0-10$ & -- & 0 & 730 & 210 & 60 & -- & 0,51 & 0,18 \\
\hline $\mathrm{E}$ & $30-40$ & -- & 0 & 840 & 120 & 40 & -- & 0,50 & 0,21 \\
\hline $\mathrm{E}$ & $60-70$ & -- & 6 & 900 & 80 & 20 & -- & 0,32 & 0,34 \\
\hline $\mathrm{E} / \mathrm{Bh}$ & $120-130$ & -- & 36 & 900 & 40 & 60 & -- & 0,29 & 0,41 \\
\hline $\mathrm{Cg}$ & $150-160$ & -- & 96 & 720 & 140 & 140 & -- & 0,33 & 0,36 \\
\hline \multicolumn{10}{|c|}{ P2: planície hidromórfica, Espodossolo Cárbico hidromórfico dúrico } \\
\hline Exc & $15-0$ & 0,99 & 0 & 740 & 200 & 60 & -- & 0,46 & 0,24 \\
\hline A & $0-20$ & 0,73 & 0 & 750 & 210 & 40 & -- & 0,40 & 0,25 \\
\hline E & $40-50$ & 1,66 & 4 & 940 & 40 & 20 & -- & 0,27 & 0,40 \\
\hline $\mathrm{Bh}$ & $75-85$ & 1,51 & 22 & 870 & 90 & 40 & -- & 0,28 & 0,42 \\
\hline $\mathrm{BhC}$ & $110-120$ & 1,52 & 54 & 820 & 80 & 100 & -- & 0,27 & 0,42 \\
\hline C & $140-150$ & 1,17 & 39 & 660 & 170 & 170 & 1,00 & 0,23 & 0,48 \\
\hline
\end{tabular}


subsuperfície no perfil T2 pode ser relacionada com a presença de nódulos ferruginosos egibbsíticos, que representam cerca de 80 \% da fração cascal ho deste solo. Estes nódulos estão também presentes na fração areia, aumentando o diâmetro médio das partículas.

A distribuição das frações de areia mostra-se relativamente uniforme entreos materiais presentes na planície e na colina (Grupo 2, Figura 5). Os materiais com granulometria mais fina (Grupo 1) constituem o material da planície hidromórfica sob interferência das minhocas, que provocam seleção das partículas finas. As areias mais grossas (Grupo 3) relacionam-se com a presença de nódulos encontrados no perfil T2.

\section{Atributos químicos do solo}

O pH em água dos solos varia de 4,4 a 5,2 na colina, diminuindo para 3,7 e 4,9, na planície hidromórfica (Quadro 3). A soma de bases é baixa, indicando ambientes com intensa desal cal inização. $\mathrm{Na}$ planície hidromórfica, nota-se maior teor de carbono orgânico $\left(\mathrm{C}_{\text {org }}\right.$ ) nas camadas superficiais e no horizonte $\mathrm{Bh}$ endurecido (P2). Os teores de Al trocável são mais altos em subsuperfície, na borda da colina e nos solos da planície hidromórfica, especialmente no horizonte $\mathrm{Bh}$ e no saprolito subjacente. A capacidade de troca catiônica (CTC) mostra relação com os teores de $\mathrm{C}_{\text {org }}$ e com a quantidade de argila. A maior CTC observada em

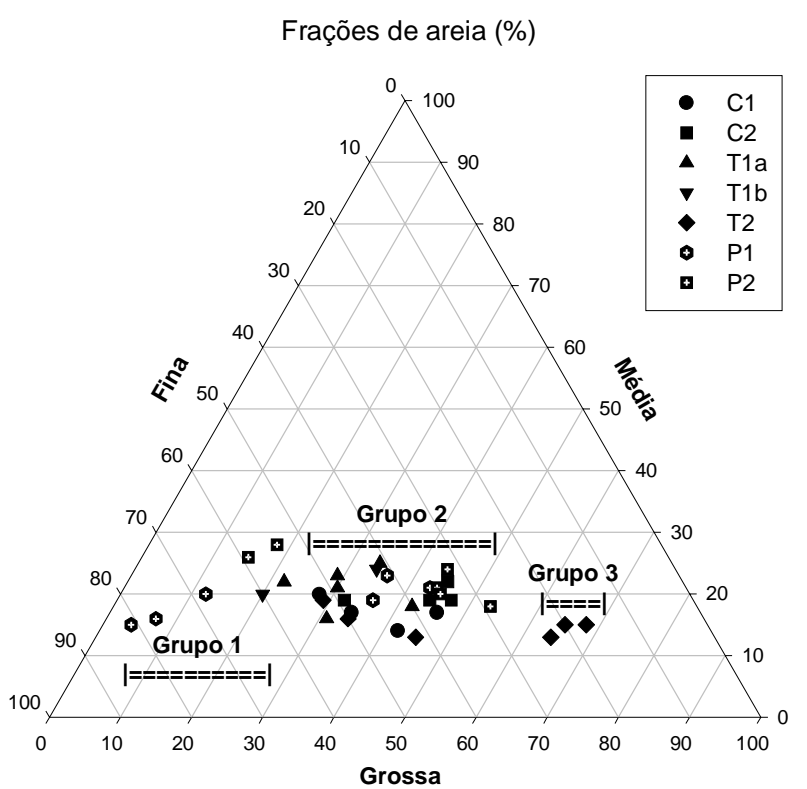

Figura 5. Distribuição das frações de areia na seqüência L atossolo-E spodossolo, sendo: Areia grossa =2-0,5 mm; Média =0,5-0,25 mm; Fina = 0,25-0,05 mm; Grupo 1: material selecionado pelas minhocas; Grupo 2: materiais de alteração do granito; Grupo 3: material com nódulos (perfil T2). subsuperfície no perfil P2 poderia ser atribuída a extração de formas amorfas de Al pelo acetato de cálcio, as quais estariam possivelmente ligadas à matéria orgânica. I sto inclusive se reflete nos maiores teores de Al trocável obtidos neste solo.

Os teores de silício obtidos por ataque sulfúrico nos horizontes superficiais dos sol os do topo da col ina são baixos, relacionados com valores de Ki próximos de 0,5 , indicando uma mineralogia oxídica. Em profundidade, a quantidade deSi,Al eFeécrescente, com maiores teores encontrados no saprolito. Os maiores teores de Fe encontrados em subsuperfície no perfil T2 podem ser atribuídos à contribuição de micronódulos de ferro presentes na terra fina $(<2 \mathrm{~mm})$.

Os solos na planície hidromórfica apresentam teores variáveis de Si e Al, sendo mais elevados na base dos perfis. A quantidade de Si em relação aoAl émaior, quando comparada à dos materiais da colina, resultando em valores de $\mathrm{Ki}$ variando de 1 a 2 . Os teores de Fe nesses solos são muito baixos, em decorrência do ambiente redutor.

\section{Composição mineralógica}

Em geral, o quartzo é o mineral mais abundante nas areias. Na col ina, os teores de feldspatos e micas na fração areia fina do horizonte Bw são inferiores a 4 \%; em profundidade, os teores são crescentes.

A fração silte mostra predomínio de quartzo, com presença mais nítida de fel dspatos dotipo microdínio em direçãoà base dos perfis. Os minerais secundários; tais como: gibbsita, caulinita e interestratificados vermiculita-ilita, são encontrados em algumas amostras (Figura 6). A gibbsita aparece na maioria das amostras analisadas e a caulinita ocorre em maior intensidade na base do perfil P1, na planície hidromórfica. A vermiculita-ilita (V-I) é encontrada tanto no saprolito da colina, como abaixo do horizonte Bh endurecidona planície hidromórfica, sendo, neste último caso, associada à mica.

Em outro perfil da planície hidromórfica (P1), as mi cas ocorrem com pouca intensi dade. A fraçãosilte, a exemplo dos grãos de areia, tem composição mineralógica relacionada com o material de origem, especialmente pela presença de feldspatos potássicos, interestratificados vermiculita-ilita e micas. A distribuição destes minerais também evidencia uma relação entre Latossol os da colina e os solos da planície hidromórfica, apontando para uma provável evolução pedogenética entre eles.

Os minerais da fração argila nos solos da colina são a gibbsita, que ocorre com picos de maior intensidade relativa nos difratogramas e, secundariamente, a caulinita, o quartzo e os minerais 2:1 (Figura 6). Esta identificação semiquantitativa de caul inita egi bbsita nos difratogramas foi também confirmada pela avaliação quantitativa feita por análise térmica diferencial. Os minerais 2:1 são 
Quadro 3. Atributos químicos do solo na seqüência Latossolo-Espodossolo

\begin{tabular}{|c|c|c|c|c|c|c|c|c|c|c|c|c|c|}
\hline \multirow{2}{*}{$\begin{array}{l}\text { Amostra } \\
\text { analisada }\end{array}$} & \multirow{2}{*}{ Profundidade } & \multicolumn{2}{|c|}{ pH } & \multirow{2}{*}{$\mathbf{A l}^{3+}$} & \multirow{2}{*}{ SB(1) } & \multirow{2}{*}{ СтC } & \multirow{2}{*}{$\mathbf{V}^{(2)}$} & \multirow[b]{2}{*}{$\mathbf{m}^{(3)}$} & \multirow{2}{*}{ C. org. ${ }^{(4)}$} & \multicolumn{3}{|c|}{ Ataque sulfúrico } & \multirow{2}{*}{$\mathbf{K i}$} \\
\hline & & Água & $\mathrm{KCl}$ & & & & & & & $\mathbf{S i}$ & Al & $\mathbf{F e}$ & \\
\hline \multicolumn{4}{|c|}{$\mathrm{cm}$} & \multicolumn{3}{|c|}{$\mathrm{mmol}_{\mathrm{c}} \mathrm{kg}^{-1}$} & \multicolumn{2}{|c|}{ - $\%$} & \multicolumn{4}{|c|}{$-\mathrm{g} \mathrm{kg}^{-1}$} & \\
\hline \multicolumn{14}{|c|}{ C1: topo da colina, Latossolo Amarelo distrófico argilossólico } \\
\hline$A$ & $0-2$ & 4,4 & 3,4 & 24 & 4,8 & 143 & 3 & 83 & 99 & $--(6)$ & -- & -- & -- \\
\hline BA & $10-20$ & 4,5 & 3,9 & 9 & & 53 & 5 & 77 & 14 & 12 & 51 & 20 & 0,46 \\
\hline $\mathrm{Bw}$ & $50-70$ & 5,0 & 4 & 1 & 2 & 59 & 5 & 27 & 8 & 24 & 81 & 37 & 0,56 \\
\hline$B C$ & $140-160$ & 5,0 & 4 & 1 & 2, & 33 & 7 & 29 & 6 & 20 & 82 & 38 & 0,47 \\
\hline $\mathrm{C}$ & $200-220$ & 4,9 & 4,1 & 2 & 2,9 & 33 & 9 & 41 & 5 & 47 & 105 & 52 & 0,85 \\
\hline \multicolumn{14}{|c|}{ T1: borda da colina, Latossolo Amarelo distrófico câmbico } \\
\hline A & $0-3$ & 4,6 & 3,8 & 12 & 2,9 & 70 & 4 & 81 & 22 & -- & -- & -- & -- \\
\hline BA & $10-20$ & 4,5 & 3,7 & 14 & 3,1 & 73 & 4 & 82 & 23 & 13 & 35 & 10 & 0,70 \\
\hline Bw1 & $50-60$ & 4,8 & 4,1 & 4 & 2,4 & 39 & 6 & 63 & 11 & 13 & 47 & 13 & 0,54 \\
\hline Bw2 & $85-95$ & 4,6 & 4,0 & 4 & 2,6 & 53 & 5 & 61 & 8 & -- & -- & -- & -- \\
\hline $\mathrm{BCg}$ & $110-120$ & 4,7 & 3,9 & 9 & 3,0 & 45 & 7 & 75 & 8 & 14 & 48 & 10 & 0,57 \\
\hline $\mathrm{BCg}$ & $125-135$ & 4,5 & 3,9 & 10 & 2,4 & 44 & 5 & 81 & 8 & 13 & 52 & 9 & 0,47 \\
\hline C & $140-150$ & 4,8 & 4,0 & 10 & 2,3 & 52 & 4 & 81 & 10 & 9 & 35 & 3 & 0,47 \\
\hline \multicolumn{14}{|c|}{ T2: borda da colina, Gleissolo Háplico Tb distrófico incéptico } \\
\hline BA & $10-20$ & 4,7 & 3,8 & 12 & 4,4 & 55 & 8 & 73 & 19 & -- & -- & -- & -- \\
\hline $\mathrm{Bi}$ & $40-60$ & 5,0 & 4,5 & 3 & 2,3 & 23 & 10 & 57 & 8 & 5 & 78 & 22 & 0,11 \\
\hline $\mathrm{CBg}$ & $80-100$ & 5,2 & 4,5 & 2 & 3,4 & 14 & 24 & 37 & 5 & 19 & 100 & 60 & 0,37 \\
\hline C & $140-160$ & 5,3 & 4,2 & 7 & 3,7 & 18 & 21 & 65 & 3 & 24 & 87 & 47 & 0,52 \\
\hline \multicolumn{14}{|c|}{ P1: planície hidromórfica, E spodossolo Cárbico hidromórfico típico } \\
\hline Exc. ${ }^{(5)}$ & $10-0$ & 4,3 & 2,8 & 15 & 4,8 & 96 & 5 & 76 & 40 & -- & -- & -- & -- \\
\hline A & 0-10 & 4,4 & 3,5 & 16 & 4,4 & 116 & 4 & 78 & 28 & -- & -- & -- & -- \\
\hline $\mathrm{E} / \mathrm{Bh}$ & $120-130$ & 4,5 & 3,7 & 9 & 3,2 & 35 & 9 & 74 & 8 & -- & -- & -- & -- \\
\hline $\mathrm{Cg}$ & $150-160$ & 4,8 & 3,8 & 13 & 2,5 & 44 & 6 & 84 & 8 & 42 & 38 & 0,3 & 2,14 \\
\hline \multicolumn{14}{|c|}{ P2: planície hidromórfica, Espodossolo Cárbico hidromórfico dúrico } \\
\hline Exc. & $15-0$ & 4,9 & 3,2 & 14 & 2,7 & 87 & 3 & 84 & 28 & 5 & 4 & 0,4 & 2,10 \\
\hline A & $0-20$ & 4,2 & 3,1 & 16 & 2,8 & 93 & 3 & 85 & 30 & 9 & 3 & 0,5 & 6,33 \\
\hline $\mathrm{E}$ & $40-50$ & 4,7 & 3,6 & 2 & 2,1 & 12 & 17 & 49 & 2 & 7 & 2 & 0,9 & 8,50 \\
\hline $\mathrm{Bh}$ & $75-85$ & 3,9 & 3,3 & $4 \overline{6}$ & 2,1 & 198 & 1 & 96 & 35 & 5 & 4 & 0,1 & 2,63 \\
\hline $\mathrm{BCh}$ & $110-120$ & 4,1 & 3,5 & 56 & 2,1 & 268 & 1 & 96 & 17 & 9 & 20 & 2,5 & 0,88 \\
\hline C & $140-150$ & 4,2 & 3,7 & 49 & 2,7 & 265 & 1 & 95 & 17 & 28 & 58 & 2,9 & 0,93 \\
\hline
\end{tabular}

(1) Soma de bases $\left(\mathrm{K}^{+}, \mathrm{Ca}^{2+}, \mathrm{Mg}^{2+}\right)$. (2) Saturação por bases. ${ }^{(3)}$ Saturação por alumínio. ${ }^{(4)}$ Carbono orgânico. ${ }^{(5)}$ Excreções de minhocas. ${ }^{(6)}$ não analisado.

vermiculitas, ilitas, interestratificados ilitavermiculita (I-V) e vermiculita-ilita (V-I), mais evidentes em subsuperfície. As ilitas somente ocorrem no horizonte C na porção superior da col ina. As vermiculitas apresentam preenchimento parcial com hidróxido de alumínio nas entrecamadas, o que se comprova pela contração a $1,0 \mathrm{~nm}$ quando aquecidas a $350^{\circ} \mathrm{C}$ e pel o espaçamento constanteem $1,4 \mathrm{~nm}$ nas amostras saturadas com $\mathrm{K}$ e $\mathrm{Mg}$. Os interestratificados I-V eV-I mostram comportamento intermediário entre vermiculita e ilita, com espaçamento basal normal menteentre 1,1 e 1,3 nm, dependendo da proporção de cada um desses minerais simples que os compõem.

Na planície hidromórfica, o perfil P1 mostra predomínio de caulinita na fração argila do saprolito.
No perfil P2, com horizonte Bh endurecido, a gibbsita é o mineral secundário predominante, associado a caulinita, ilitas eilita-vermi culita em subsuperfície, no horizonte $\mathrm{C}$.

\section{Uniformidade e filiação dos materiais}

Os solos na colina apresentam as seguintes evidências de filiação genética em relação ao material de origem subjacente: (a) diminuição progressiva no diâmetro das areias em direção à superfície, (b) uniformidade quanto à esfericidade e arredondamento dos grãos de quartzo e (c) composição mineralógica dependentedos constituintes do granito, com modificações progressivas na estrutura de microgranular para maciça e na quantidade de micas e fel dspatos no esqueleto. 

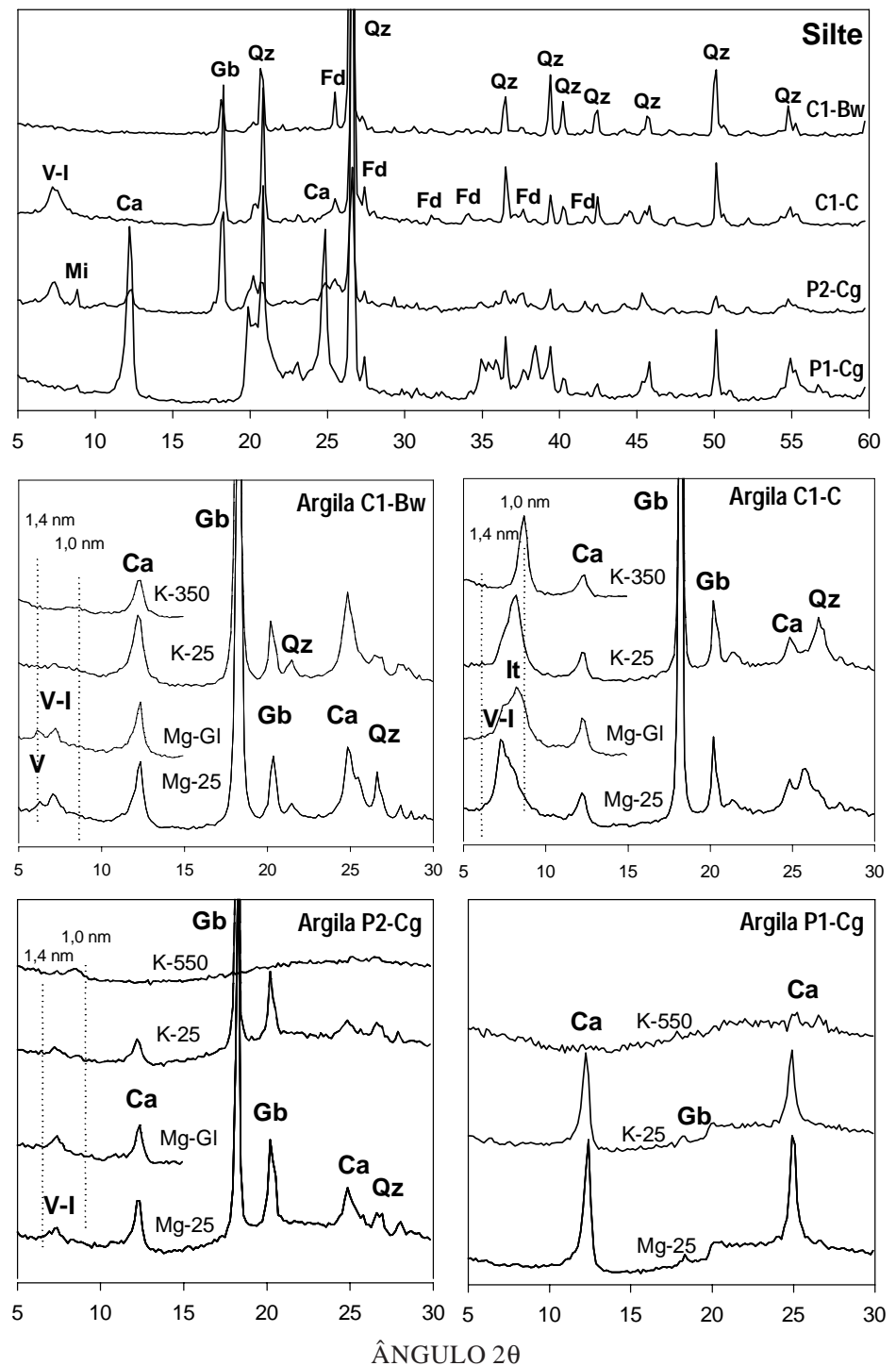

Figura 6. Difratogramas de raios-X da fração silte e argila deferrificada, sendo: $C a=$ caulinita, $F d=$ feldspatos; Gb = gibbsita; I-V =ilita-vermiculita; It =ilitas; Mi =micas; Qz =quartzo; V =vermiculitas; V-I = vermiculita-ilita.

Várias evidências também comprovam a relação genética entre os solos da planície hidromórfica e o substrato rochoso, quais sejam: (a) presença de litorrelíquias no topo do horizonte Bh endurecido, (b) uniformi dade na distribuição das frações de areia e no arredondamento e esfericidade dos grãos de quartzo, (c) ausência de qualquer evidência que testemunharia uma estrutura sedimentar nas areias brancas e d) disposição organizada dos materiais de alteração relacionados com o aprofundamento progressivo da rocha à medida que se distancia da colina. Numa faixa circundando a colina, tem-se a presença de areia branca diretamente sobre a rocha. Nas porções mais afastadas da colina, verificam-se saprolito de granito ou material areno-argil oso claro de alteração em subsuperfície, que se aprofundam e são cobertos pela camada de areia branca.
A composição mineralógica oferece outras evidências da dependência entre os constituintes do sol o e o granito na planície hidromórfica. Verificouse a presença de ilita e vermiculita-ilita, na fração argila, de micas, na fração silte, e de feldspatos, nas frações silte e areia fina, inclusive no conjunto arenoso superior $(E)$.

\section{Diferenciação dos solos da colina e formação das areias brancas}

Os solos na colina têm horizonte Bw pouco espesso, ao mesmo tempo que apresentam alter ação bastante avançada dos minerais primários, restando pequena quantidade $(<4 \%)$ de feldspatos e micas nas areias, coexistindo com grandes quantidades de gibbsita na fração argila. A formação deste mineral 
como resultado da al teração de rochas ácidas como o granito necessita de meio com drenagem rápida e com baixa atividade de $\mathrm{H}_{4} \mathrm{SiO}_{4}$ em solução (Macias \& Chesworth, 1992). Esses Latossolos com mineralogia da fração argila predominantemente gibbsítica diferem de outros L atossolos Amarel os da Amazônia brasileira, caracterizados principalmente em áreas sedimentares, com mi neral ogia das argilas predominantemente caulinítica (Kitagawa \& M oller, 1979). O avançado estádio de intemperismo desses sol os podeser constatado pela baixa relaçãosilte/argila (Resende et al., 1995) e pel os baixos valores de Ki, que refletem perda intensa de silício, enquadrandoos no domínio da hidrólise total ou alitização, segundo Melfi \& Pedro (1977).

Nesses solos da colina, observam-se variações laterais influenciadas pelo hidromorfismo, com mudança na cor do saprolito, passando de vermel ho para amarelado (Figura 3a) edepois para acinzentado na borda da colina. Essa diferenciação relaciona-se com a dissolução dos óxidos de ferro, sendo a hematita preferencialmente atacada em relação à goethita (J eanroy et al., 1994). A partir daí, em meio alagado, os óxidos de ferro são el iminados na forma reduzida. A deferruginização constatada no material acinzentado em subsuperfíciena borda da col ina está ligada à perda da estrutura em agregados, conferindo aspecto maciço eocasionando aumento da densidade do solo (Quadro 2).

O desenvolvimento das zonas arenosas abai xo do conjunto latossólico na borda da colina ocorre da seguinte forma: inicialmente, aparecem pontuações milimétricas descol oridas eisoladas, que surgem no material mosqueado (Figura 3b). Em profundidade, essas porções arenosas tornam-se maiores e coalescem (Figura 3c). Esta disposição em pontuações local izadas que progressivamenteformam o conjunto arenoso em subsuperfície, abaixo do material amarelo latossólico, em contato com a planície hidromórfica, evidencia a transformação lateral dos Latossolos em areias. Os contornos fortemente recortados na zona de contato colina-planície, com presença de depressões fechadas no sopéda col ina e montículos arredondados que constituem relíquias de uma parte da colina, totalmente isolados pelo material arenoso, reforçam a existência de uma relação entre os Latossolos e as areias da planície hidromórfica.

\section{Processos pedogenéticos envolvidos}

A formação de sol os arenosos como Espodossol os tem sido verificada em diferentes condições nas regiões tropicais úmidas. Inicialmente, pensava-se que os Espodossolos tropicais somente se desenvolvessem a partir de rochas arenosas, tais como: quartzitos, arenitos ou outros materiais resultantes de coluvionamento e transporte eólico ou hídrico. No caso dos Espodossolos e outros solos arenosos que ocorrem nas baixadas da bacia amazônica, sua formação foi inicialmente atribuída à deposição de sedimentos nas bordas dos vales (Klinge, 1965; Sombroek, 1984).

A erosão mecânica poderia ser um dos processos envolvidos na diferenciação textural dos materiais na borda da colina, a qual seria favorecida pela desestabilização da agregação, em virtude da perda dos óxidos de ferro. A ação da erosão superficial parece exercer papel secundário nos sol os estudados, pois a superfície do sol o encontra-se constantemente coberta pelas plantas e serapilheira, protegendo-o contra a desagregação. Na superfície do solo, não foram identificados sinais de erosão hídrica, assim como não foram constatados nos perfis estudados quaisquer sinais macro ou micromorfológicos que indicassem transporte ou deposição de argilas. Além disso, a ação da erosão mecânica dificilmente poderia explicar a formação de barrancos com as paredes acentuadamente inclinadas e o desenvolvimento de uma depressão fechada.

Em contraposição à hipótese de origem sedimentar, vários estudos realizados na Guiana Francesa eno Brasil têm mostrado que E spodossolos podem ser formados pela transformação de uma cobertura latossólica inicial, sobre vários tipos de material deorigem (Lucas et al., 1984; Andrade, 1990; Dubroucq et al., 1991). Neste caso, o E spodossolo é considerado como um estádio final de degradação das coberturas pedológicas tropicais (Boulet et al., 1984).

Esta hipótese de evolução pedogenética mostrase mais adequada para explicar a diferenciação Latossolo-E spodossol o por nós estudada, baseandose nas evidências de uniformidade e filiação dos materiais ao granito e na disposição organizada dos constituintes do solo da colina à planície.

A ferrólise é um dos processos pedogenéticos indicado como responsável na transformação de Latossol os para sol os arenosos em outras situações na Amazônia. Este processo foi inicialmente verificado em planossolos do Paquistão, que desenvolviam gradiente textural abrupto entre o horizonte $\mathrm{A}$ e $\mathrm{B}$, numa estreita camada de alguns centímetros, em condições contrastadas de umectação e dessecação (Brinkman, 1970). Andrade (1990) refere-se à partici pação deste processo, agindo juntamente com a acidólise, para explicar a diferenciação de solos formados sobre rochas cristalinas, na região sul de Roraima.

E m outro estudo, esses dois processos são citados como responsáveis pela diferenciação de Latossol os em N eossolos Quartzarênicos, desenvolvidos sobre sedimentos da Formação Barreiras no sul do Pará (Demattê et al., 1994). Salienta-se, entretanto, que esse processo de ferrólise supostamente não se desenvolve no ambiente por nós estudado, onde os sol os são constantemente úmi dos e as flutuações do nível freático são pouco intensas. 
Muito provavelmente, o processo pedogenético envolvido com mais destaquena perda deargila nesses sol os éa erosão geoquímica ou dissolução, favorecida pela desestabilização estrutural, em virtude da perda dos óxidos de ferro. Este processo parece ser o mais verossímil tanto na explicação da formação das depressões fechadas, como das demais diferenciações pedológicas verticais e laterais constatadas.

A dissolução das argilas e o conseqüente empobrecimento dos materiais ocorrem neste ambiente principalmente em decorrência da acidólise (Melfi \& Pedro, 1978), a partir da solubilização das argilas em pH baixo $(<5)$ eda ação de soluções que contêm ácidos orgânicos provenientes da decomposição parcial da fitomassa em meio anaeróbio. Muitos desses ácidos são capazes de complexar o Al, intensificando a destruição dos minerais (Ribeiro, 1998). A acidez pode também ser advinda da absorção de cátions pelas plantas e, ou, resultante do $\mathrm{CO}_{2}$ produzido pela respiração radicular (Grimaldi \& Pedro, 1996). Algumas determinações da acidez das águas escuras efetuadas no rio Negro, em Cucuí, AM, nas proximidades do local de estudo, indicaram valores de $\mathrm{pH}$ entre 3,5 e 4,5 (UnB, 1999); semel hantes aos valores relatados por Sioli (1975) em avaliações feitas na região do alto rio N egro.

\section{Transformação Latossolo-E spodossolo}

A transformação de Latossol os em solos arenosos como Espodossolos foi verificada na Amazônia em materiais formados sobre rochas sedimentares (Lucas, 1989) ou mesmo sobre o embasamento cristalino (Andrade, 1990; Dubroeucq \& Volkoff, 1998). Nestes estudos, observa-se o desenvolvimento do processo de acidólise no interior do conjunto latossólico, que mostra gradual empobrecimento lateral em argila em direção à porção inferior das vertentes. I sto difere do caso ora em estudo, onde esta diferenciaçãoé mais abrupta ese processa numa escala métrica, principalmente abaixo do nível do Iençol freático, agindo sobre o saprolito.

A formação dos solos na planície hidromórfica envolve a transformação de uma cobertura latossólica preexistente, cuja dinâmica lateral com dissolução dos argilominerais deixaria como resíduo o esqueleto quartzoso, formando uma camada de areia branca sobre a rocha. Esta interpretação é corroborada em Dubroeucq et al. (1991); Dubroeucq \& Volkoff (1998) eThomas et al. (1999).

\section{CONCLUSÕES}

1. A cobertura pedológica composta por solos arenosos hidromórficos associados a Latossolos mostra evidências morfológicas e analíticas que indicariam um desenvolvimento autóctone e sua filiação ao granito subjacente.
2. Os Latossolos transformar-se-iam em subsuperfície, a partir das bordas da colina, dependendo das condições de saturação hídrica. A formação do material arenoso na base do conjunto latossólico, decorrente do contato com as águas ácidas da planíciehidromórfica, desestabilizaria edegradaria as argilas.

3. O principal processo pedogeoquímico envolvido na perda deargila na borda da colina seria a acidól ise, provocando dissolução de gi bbsita e caulinita.

4. A formação do horizonteBh e, conseqüentemente, do Espodossolo hidromórfico seria posterior à formação das areias brancas hidromórficas que circundam a colina.

5. O mecanismo envolvido na transformação dos Latossol os em areias brancas hidromórficas podeser ainda o principal mecanismo responsável pelo aplainamento geral do terreno observado nesta região.

\section{AGRADECIMENTOS}

Trabalho financiado pelo Ministério da Ciência e Tecnologia (PRONEX, 1997) e pela Fundação de Amparo à Pesquisa do estado de São Paulo. Os autores agradecem ao Dr. Enio Fraga da Silva (EMBRAPA, Solos), pel o auxílio na classificação dos solos, e ao Engenheiro Ney Pinheiro Sampaio, do Núcleo de Pesquisa em Geoquímica e Geofísica da Litosfera (NUPEGEL/USP), pela obtenção dos difratogramas de raios-X.

\section{LITERATURA CITADA}

ANDRADE, H. Evolução de uma seqüência de solos argilosos até arenosos no Complexo Guianense da Amazônia. Piracicaba, Escola Superior de Agricultura "Luiz de Queiroz", 1990. 179p. (Tese de Doutorado)

BOULET, R.; CHAUVEL, A. \& LUCAS, Y. Les systémes de transformation en pédologie. In: Livre J ubilaire du Cinquantenaire de Association Française pour l'Étude du Sol. Paris, AFES, 1984. p.167-179.

BRAMMER, H. Pozols in Zambia. Geoderma, 10:249-250, 1973.

BRASIL. Ministério das Minas e Energia. Departamento Nacional da Produção Mineral. Projeto Radambrasil. Fol ha NA.19 Pico da Neblina. Rio deJ aneiro: MME/DNPM, 1976. 374p. (Levantamento de Recursos Naturais, 11)

BRINDLEY, G.W. \& BROWN, G. X-ray diffraction procedures for clay mineral identification. London, Mineralogical Society, 1984. 495p.

BRINKMAN, R. Ferrolysis, a hydromorphic soil forming process. Geoderma, 3:199-206, 1970.

BULLOCK, P.; FEDEROFF, N.; J ONGERIUS, A.; STOOPS, G. \& TURSINA, T. Handbook for soil thin section description. London, Waine Research Publications, 1985. 152p. 
CAMARGO, O.A.; MONIZ, A.C.; J ORGE, J.A. \& VALADARES, J.M.A.S. Métodos de análise química, mineralógica e física de solos. Campinas, Instituto Agronômico de Campinas, 1986. 94p. (Boletim Técnico, 106)

CASTRO, S.S. I mpregnação de amostras de solo para confecção de lâmina delgada. B. Inf. SBCS, 10:44, 1985.

DEMATTE,J .A.M.;ALOISI,R.R. \& DEMATTE, J .L.I . Seqüência Latossolo Amarelo, Podzólico Amarelo, Areias Quartzosas sobre material da Formação Barreiras na região deTucuruí, Estado do Pará. Sci. Agric., 51:345-356, 1994.

DUBROEUCQ, D. \& BLANCANEAUX, P. Les podzols du haut rio Negro, region de Marao, Venezuela. Environnement et relations lithologiques. In: RIGHI, D. \& CHAUVEL, A., eds. Podzols et podzolisation. Paris, INRA, 1987. p.37-52.

DUBROEUCQ, D. \& VOLKOFF, B. From Oxisols to Spodosols and $\mathrm{H}$ istosols: evolution of the soil mantles in the rio Negro basin (Amazonia). Catena, 32:245-280, 1998.

DUBROEUCQ, D.; VOLKOFF, B. \& FAURE, P. Les couvertures pédologiques à Podzols du bassin du haut rio Negro (Amazonie). Étude Gestion Sol, 6:131-153, 1999.

DUBROEUCQ, D.; VOLKOFF, B. \& PEDRO, G. La couverture pédologique du bouclier du nord de l'Amazonie (bassin du Haut rio Negro). Séquence évolutive des sols et son rôle dans I'aplanissement généralisé des zones tropicales perhumides. C. R. Acad. Sci., Sér. II, 312:663-671, 1991.

EMPRESA BRASILEIRA DE PESQUISA AGROPECUÁRIA EMBRAPA. Serviço Nacional de Levantamento e Conservação de Solos. Mapa de solos do Brasil. Rio de J aneiro, EMBRAPA/SNLCS, 1981. (Escala 1:5.000.000)

EMPRESA BRASILEIRA DE PESQUISA AGROPECUÁRIA EMBRAPA. CentroNacional dePesquisa de Solos. Sistema brasileiro de classificação de solos. Rio de J aneiro, 1999. $412 \mathrm{p}$.

FOLK, R.L. \& WARD, W.C. Brazos river bar: a study on the significance of grain-size parameters. J. Sed. Petrol., 27:326, 1957.

GAVAUD, M.; BLANCANEAUX, P.; DUBROEUCQ, D. \& POUYLLAU, M. Les paysages pédologiques de l'Amazonie venezuelienne. Cah. Orstom, Sér. Pédol., 22:265-284, 1986.

GRIMALDI, C. \& PEDRO, G. I mportance de I'hydrolyse acide dans les systèmes pédologiques des régions tropicales humides. C.R. Acad. Sci., Paris, Sér. II a, 323:483-492, 1996.

GRZEBYK, M. \& DUBROEUCQ, D. Quantitative analysis of distribution of soil types: existence of an evolutionary sequence in Amazonia. Geoderma, 62:285-298, 1994.

J ACKSON, M.L. Soil chemical analysis: Advanced Course. Madison, University of Wisconsin, 1969. 895p.

JEANROY, E.; RAJ OT, J.L.; PILLON, P. \& HERBILLON, A.J . Differential dissolution of hematite and goethite in dithionite and its implication on soil yellowing. Geoderma, 50:79-94, 1991.

KITAGAWA, Y. \& MOLLER, R.F. Clay mineralogy of sometypical soils in the brazilian amazon region. Pesq. Agropec. Bras., 14:201-228, 1979.

KLINGE, H. Podzol soils in the amazon basin. J. Soil Sci., 16:95-103, 1965.

KRUMBEIN,W.C. \& SLOSS, L.L. Stratigraphy and sedimentation. 2.ed. San Francisco, W.H. Freeman and Company, 1963. 660p.
LEMOS, R.C. \& SANTOS, R.D. Manual de descrição e coleta de solo no campo. 3.ed. Campinas, Sociedade Brasileira de Ciência do Solo, 1996. 83p.

LUCAS, Y. Systèmes pédologiques en Amazonie brésilienne. Equilibres, déséquilibres et transformations. Paris, Universite Poitiers, 1989. 157p. (Tese de Doctorado)

LUCAS Y.; CHAUVEL A.; BOULET R.; RANZANI G. \& SCATOLINI F. Transição Latossolos-podzóis sobre a formação Barreiras na região de Manaus, Amazônia. R. Bras. Ci. Solo, 8:325-335, 1984.

MACIAS, F. \& CHESWORTH, W. Weathering in humid regions, with emphasis on igneous rocks and their metamorphic equivalents. In: MARTINI, I.P. \& CHESWORTH, W., eds. Weathering, soils and paleosols. Amsterdam, Elsevier, 1992. p.283-306. (Developments in Earth Surface Processes, 2)

MELFI, A.J . \& PEDRO, G. Estudo geoquímico dos solos e formações superficiais do Brasil. 1. Caracterização e repartição dos principais tipos de evolução pedogeoquímica. R. Bras. Geoc., 7:271-286, 1977.

MELFI, A.J . \& PEDRO, G. Considerações sobre os mecanismos geoquímicos envolvidos na alteração superficial e sua repartição no Brasil. R. Bras. Geoc., 8:11-22, 1978.

MOORE, D.M. \& REYNOLDS J r., R.C. X-ray diffraction and identification and analysis of clay minerals. Oxford, Oxford University Press, 1989. 332p.

RESENDE, M.; CURI, N.; REZENDE, S.B. \& CORRÊA, G.F. Pedologia: base para distinção de ambientes. Viçosa, NEPUT, 1995. 304p.

RIBEIRO, L.P. Os Latossol os Amarelos do Recôncavo Bahiano: gênese, evolução e degradação. Salvador, Seplantec, CADCT, 1998. $99 p$.

SCHWARTZ, D. Les podzols tropicaux sur sables Bateke en R.P. du Congo. Description, caracterisation, genese. In: RIGHI, D. \& CHAUVEL, A., eds. Podzols et podzolisation. Paris, INRA, 1987. p.25-36.

SIOLI, H. Tropical rivers as expressions of their terrestrial environments. In: GOLLEY, F.B. \& MEDINA, E., eds. Tropical ecological systems: Trends in terrestrial and aquatic research. Berlin, Springer Verlag, 1975. p.275288.

SOMBROEK, W.G. Soil of the Amazon region. In:TheAmazon: Limnol ogy and landscape ecology of a mighty tropical river and its basin. Dordrecht, W. J unk Publication, 1984. p.522535.

SUGUIO, K. Introdução à sedimentologia. São Paulo, Edgar Blucher/EDUSP, 1973. 317p.

THOMAS, M.F.; THORP, M. \& MCALISTER, J. Equatorial weathering, landform devel opment and formation of white sands in north western Kalimantan, Indonesia. Catena, 36:205-232, 1999.

UNIVERSIDADE DE BRASÍLIA - UnB. Hidrologia egeoquímica da bacia amazônica. http//www.unb.br/ig/hibam/ campanhas. 29/Dez/1999.

van LIER, Q.J . \& VIDAL-TORRADO, P. Phi: programa de microcomputador para análise estatística da granulometria de sedimentos. R. Bras. Ci. Solo, 16:277-281, 1992.

VOLKOFF, B. Organizations régionales de la couverture pédologique du Brésil. Chronologie des différenciations. Cah. Orstom, Sér. Péd., 21:225-236, 1985. 